International Journal of Biology, Pharmacy and Allied Sciences (IJBPAS)

'A Bridge Betuen Caboratory and QRendo'

Www.ibpas.com

\title{
A SYSTEMATIC REVIEW ON PHARMACEUTICAL PICTOGRAMS
}

\section{DAI O AND JOSHI Y*}

Department of Pharmacy Practice, School of Pharmaceutical Sciences, Shri Guru Ram Rai University, Dehradun-248001, Uttarakhand (India)

*Corresponding Author: Yogesh Joshi: E Mail: yogeshioshi1583@rediffmail.com

Received 25 ${ }^{\text {th }}$ March 2020; Revised $20^{\text {th }}$ April 2020; Accepted $15^{\text {th }}$ July 2020; Available online $1^{\text {st }}$ Jan. 2021

\section{https://doi.org/10.31032/IJBPAS/2021/10.1.5295}

\begin{abstract}
Poorly understood and low retention of verbal form of medication information by the patients could lead poor health outcomes and non-adherence. Hence, using pictograms in a combination with writing and simple explanation may greatly improve the patients' understanding regarding their prescribed medication and enhanced compliance. This systematic review was conducted to examine potential interpretation and understanding of pharmaceutical pictograms by participants. A search of articles was conducted using several key terms on various databases, followed by manual sorting of the references of those articles that included. The research identified 39 studies, after screening only 13 studies that fulfilled the criteria were selected. This study showed that some existing pictograms were difficult to interpret but prior explanation could increase the understanding of these pictograms. However, before implementing in practice, further development and evaluation of study design with required intervention needed compulsorily.
\end{abstract}

Keywords: Pictograms, compliance, interpretation, explanation, articles \section{INTRODUCTION}

Health literacy is required to comprehend basic health information and services. The capability of an individual based on health literacy is required to make appropriate health decisions. Those with low health literacy are elderly of over 65 years, belong to minority groups, are immigrants or refugees, may have a low socioeconomic status, have a low educational level, or are non-native speakers [1]. People with low health literacy have a poorer health status, less knowledge about their disease and its 
treatment; fewer appropriate selfmanagement skills, increased hospitalizations, increased health costs and poorer adherence rates $[\mathbf{2}, \mathbf{3}]$. Thus, the challenge facing by the health care provider is to communicate effectively to educate them about their drug therapies in an appropriate, understandable form appropriate with the patients' literacy skills and furthermore to ensure that it is conventional in terms of patient's culture, beliefs, attitudes and expectations [4-6]. The use of stylized figurative drawing i.e. pictograms can help in making medication information more understandable and recall if used appropriately which can even result in better health outcome [7].

Pictograms are the graphical representation to convey variable instructions on objects or actions and considered to be a part of international language and can be easily recognized with their intended meaning with little or no dependence on any particular culture or language [8]. The United States Pharmacopoeia (USP) convention defined pharmaceutical pictograms as "standardized graphic images that easily convey some medication instructions precautions and warnings to patients and their relatives" [9]. They have been designed to aid passing on essential information to all patients, including those for whom English is second language, who are visually impaired, low literacy and also for the literate persons which can serve as one of the easiest, the most significant means of providing information to patients that improving both understanding and adherence. They may improve warning comprehension and can sometimes be recognized and remembered far better than words. The success of pictogram as a communication aid rests on its design and testing process in order to produce acceptable pictogram, and their proper use by healthcare professional who must use pictogram in combination with oral and text containing information [10, 11].

The design and evaluation of pictograms is a complex and multistage process. To find out the target population and to involve that population in all stages of the design; evaluation process is one of the main approaches to minimize problems when designing pictograms. The pictograms should primarily be tested among healthy respondents from the selected population and the successful designs should be tested in practice in a patient population to monitor for the effect of pictograms on the understanding of instructions and on compliance for drug therapy. In determining on the acceptability of a pictogram, researchers need to be guided by international standards which have been well-known for evaluating the comprehensibility of pictorial symbols. The American National Standards Institute 
(ANSI Z535.3) and the International Standards Organization's (ISO 3864) \& (ISO 1986) advise that, in a comprehension test, pictorial symbols must reach at least a criterion of $85 \%$ or $67 \%$ or $66 \%$ correct, respectively. These standards may be considered arbitrary, but given the importance of understanding the correct medication instructions in order to use a medicine safely, comprehension should be above the $85 \%$ level if possible [12].

\section{Search Strategy}

This was a systematic literature review where the relevant articles were initially started searching by using the following terms: pharmaceutical pictogram or pictograph or pictorial or graphics or visual or symbol and evaluation of pictogram, followed by manual searches of the references in those articles that had inclusion criteria and purposes that were related to those of this review. To be included, these studies must be published in English language, published year should not be older than year 1995; complete articles available in databases; heterogeneous regarding study setting, study design, the number of participants, study population; and studies included must use general pharmaceutical pictograms to assess their transparency or understanding among participant rather than for patient's medication education. Reviews and letter to the editor were excluded from this study.

\section{Data Extraction}

Initially, 30 articles were obtained through web-based search, followed by additional 9 articles by way of manual search in the reference of those articles, for a total of 39. After screening the 39 articles based on inclusion criteria, 26 articles were excluded because they were editorial or duplicate or review or presented only abstracts, were not publish in English or simply they did not meet the inclusion criteria.

\section{Analysis}

The web-based search and the manual search yielded a final total of 13 articles that met the inclusion criteria, were published from 1995 to 2018. The studies' sample sizes vary from 45 to 385 , and the participants' age ranges from $\geq 18$ to 96 years. The participants' ethnicities were diverse: Latino, African American, Persian, and Asian. The general characteristic of the final 13 articles included in this review were summarized in the tabulated form (Table 1). 


\begin{tabular}{|c|c|c|c|c|c|c|}
\hline $\begin{array}{l}\text { Corresponding Author with } \\
\text { Year }\end{array}$ & $\begin{array}{c}\text { Study Setting, } \\
\text { Country }\end{array}$ & Study Design & $\begin{array}{c}\text { Study Population } \\
\text { Characteristics }\end{array}$ & $\begin{array}{l}\text { Number \& Types } \\
\text { of Pictograms }\end{array}$ & $\begin{array}{l}\text { Duration of } \\
\text { the Study }\end{array}$ & Outcomes \\
\hline Merks P et al. 2018 [13] & $\begin{array}{c}\text { Community } \\
\text { pharmacy, Poland }\end{array}$ & Pilot study & $\begin{array}{c}N=68 \\
\text { Elderly patient's } \\
\geq 65 \text { years }\end{array}$ & $\begin{array}{l}\text { Local pictogram } \\
\quad=22\end{array}$ & NR & $\begin{array}{c}\text { All pictograms obtained an acceptable } \\
\text { transparency level } \geq 66 \% \text { \& passed the short- } \\
\text { term recall test. }\end{array}$ \\
\hline Kanji L et al.2018 [14] & $\begin{array}{l}\text { Hindu community, } \\
\text { Portugal }\end{array}$ & Cross-sectional study & $\begin{array}{c}\mathrm{N}=50 \\
\text { Hindu individuals } \\
>18 \text { years }\end{array}$ & $\begin{array}{l}\text { USP-DI }=15 \\
\text { FIP }=15\end{array}$ & 6 months & $\begin{array}{l}\text { The USP pictograms were better interpreted } \\
\text { than FIP pictogram. }\end{array}$ \\
\hline $\begin{array}{l}\text { Mohamed LMA et al.2018 } \\
{[15]}\end{array}$ & $\begin{array}{l}\text { Out-patients, } \\
\text { Khartoum North, } \\
\text { Sudan }\end{array}$ & $\begin{array}{c}\text { Cross-sectional, } \\
\text { observational, } \\
\text { questionnaire based } \\
\text { study } \\
\end{array}$ & $\begin{array}{l}N=385 \\
\text { Sudanese patients } \\
\geq 18 \text { years }\end{array}$ & $\begin{array}{l}\text { Sudanese labelled } \\
\text { pictograms }=26\end{array}$ & 2 months \& & $\begin{array}{c}\text { Participants' level of correct interpretation of } \\
\text { pictograms was } 82.76 \% \text {. }\end{array}$ \\
\hline$\underset{[16]}{\text { Zargarzadeh AH et al. } 2017}$ & $\begin{array}{l}\text { Community, } \\
\text { Iran }\end{array}$ & Cross-sectional study & $\begin{array}{c}\mathrm{N}=\mathbf{3 5 8} \\
\text { Farsi speakers }\end{array}$ & $\begin{array}{c}\text { Study-1 } \\
\text { USP-DI=3 } \\
\text { Study-2 } \\
\text { USP-DI=3 }\end{array}$ & 6 months & $\begin{array}{l}\text { Improvement in initial understanding of all } \\
\text { three pictograms } \\
\text { Improvement in understanding in the follow- } \\
\text { up stage of all three pictograms }\end{array}$ \\
\hline Barros IMC et al. 2014 [17] & $\begin{array}{l}\text { Institutions, } \\
\text { Brazil }\end{array}$ & $\begin{array}{l}\text { Cross-sectional } \\
\text { observational \& } \\
\text { interview study }\end{array}$ & $\begin{array}{l}\quad \mathrm{N}=166 \\
\text { Elderly Brazilians }\end{array}$ & USP-DI=15 & 5 months & $\begin{array}{l}\text { Maximum of the pictograms were not } \\
\text { understand by the participants. }\end{array}$ \\
\hline Sharif SI et al. 2014 [18] & $\begin{array}{l}\text { University of } \\
\text { Sharjah, United } \\
\text { Arab Emirates }\end{array}$ & Cross-sectional study & $\begin{array}{c}\mathrm{N}=\mathbf{3 0 0} \\
\text { Pharmacy and } \\
\text { Non-Pharmacy students }\end{array}$ & USP-DI=28 & 3 months & $\begin{array}{l}\text { only } 2 \text { pictograms were understand by } \\
\text { students. }\end{array}$ \\
\hline Joshi Y et al. 2011 [11] & $\begin{array}{l}\text { Outpatients, } \\
\text { Dehradun, India }\end{array}$ & $\begin{array}{l}\text { Pre-post interventional } \\
\text { study }\end{array}$ & $\begin{array}{l}\mathrm{N}=\mathbf{2 0 0} \\
\text { Illiterate patients }\end{array}$ & USP-DI=10 & NR & $\begin{array}{c}\text { In pre-interventional phase - } 1 \% \text { patients } \\
\text { interpreted the meaning of pictograms. } \\
\text { After explanation - improvement in patients' } \\
\text { interpretation for pictograms. } \\
\end{array}$ \\
\hline Knapp P et al. 2005 [19] & $\begin{array}{l}\text { Primary Care } \\
\text { Practice, England }\end{array}$ & $\begin{array}{c}\text { Part-1 } \\
\text { Cross-sectional study } \\
\text { Part- } 2 \\
\text { Randomized controlled } \\
\text { design }\end{array}$ & $\begin{array}{c}\mathrm{N}=160 \\
\text { Adults } \\
\text { Age 17-83 years } \\
\mathrm{N}=67 \\
\text { Older adults } \\
\text { Age 65-96 years }\end{array}$ & $\begin{array}{l}20 \text { pictogram }(10 \\
\text { USP \& 10 South } \\
\text { African pictogram) } \\
10 \text { small or large } \\
\text { USP pictograms }\end{array}$ & NR & $\begin{array}{c}\text { Interpretation rates ranges from } 7.5-90 \% \text {. } \\
\text { Pictograms are better understood if they were } \\
\text { larger. }\end{array}$ \\
\hline Dowse R et al. 2004 [20] & $\begin{array}{l}\text { Mixed community, } \\
\text { South Africa }\end{array}$ & NR & $\begin{array}{c}\mathrm{N}=304 \\
\begin{array}{c}\text { South African language } \\
\text { groups }\end{array}\end{array}$ & $\begin{array}{l}46 \text { pictograms ( } 23 \\
\text { USP-DI \& } 23 \text { Local } \\
\text { pictograms) }\end{array}$ & NR & $\begin{array}{l}\text { Interpretation of USP pictograms } 14 \% \text { to } \\
97 \% \text {. } \\
\text { Local pictograms more correctly interpreted } \\
\text { and preferred than USP pictograms. } \\
\end{array}$ \\
\hline Dowse R et al. 2003 [21] & $\begin{array}{c}\text { Community, South } \\
\text { Africa }\end{array}$ & NR & $\begin{array}{c}\mathbf{N}=\mathbf{1 3 0} \\
\text { Xhosa Respondents }\end{array}$ & $\begin{array}{c}46 \text { pictograms ( } 23 \\
\text { USP-DI \& } 23 \text { Local } \\
\text { pictograms) }\end{array}$ & NR & $\begin{array}{l}\text { Interpretation rate increases with increasing } \\
\text { education level. } \\
\text { Local pictograms are more preferable than USP. }\end{array}$ \\
\hline Dowse R et al. 2001 [22] & $\begin{array}{l}\text { Local black } \\
\text { community, } \\
\text { South Africa }\end{array}$ & NR & $\begin{array}{l}\mathrm{N}=46 \\
\begin{array}{l}\text { Black people of Xhosa } \\
\text { group }\end{array}\end{array}$ & $\begin{array}{l}46 \text { pictograms } \\
\text { (23 USP-DI \& } 23 \\
\text { local pictograms) }\end{array}$ & NR & $\begin{array}{l}\text { In pre-follow up - } 30.0 \% \text { Local pictograms \& } 8.7 \% \\
\text { USP. } \\
\text { In post-follow up - 87.0\% Local pictograms \& } \\
\text { 47.8\% USP. Improvement in patients' interpretation } \\
\text { after explanation } \\
\end{array}$ \\
\hline Hanson EC et al. 1995 [6] & $\begin{array}{l}\text { Nursing homes, } \\
\text { North Carolina }\end{array}$ & Interview & $\begin{array}{c}\mathrm{N}=45 \\
\begin{array}{c}\text { Elderly and low-literate } \\
\text { patients }\end{array}\end{array}$ & 14 USP-DI & NR & $\begin{array}{c}\text { Before counselling } 54 \% \text { of pictograms were } \\
\text { interpret incorrectly which reduced to } 34 \% \\
\text { after counselling }\end{array}$ \\
\hline
\end{tabular}

IJBPAS, January, 2021, 10(1) 


\section{DISCUSSION}

In this review, we have assessed studies designed to evaluate understanding of pharmaceutical pictogram amongst participants. We primarily focus on the studies that utilized pictograms to assess the transparency of pictograms rather than for patients' medication education. Hence, limited 13 relevant articles were selected. Research showed that studies evaluated 2 sets of pictograms such as local pictograms and standard pictogram (USP-DI \& FIP) and out of total 13 articles, 10 articles have implemented a total of 50 different standard pictograms amongst which 3 commonly used pictograms were (A) Store in refrigerator (B) This medicine may make you drowsy (C) Do not drink alcohol while taking in medicine. The review suggests several key findings:

First, the process of interpreting unfamiliar pictogram was a tiring, challenging one, particularly for those respondents with less education and limited visual literacy skills [21, 22]. The standard education had a significant influence on interpretation of pictogram that is higher the level of education the more likely to interpret correctly as compared to those with lower education [15, 19-21]. A study suggested that pictogram was better understood if they were larger in size especially in elderly population. Nevertheless, both the pictogram size and at repeat presentation after explanation were independent predictors of correct interpretation. In addition, older ones were less likely to interpret pictogram more correctly than younger age, may be because of cognitive and education deficit with the increasing age $[15,17,19]$.

Second, on evaluating both the local and USP pictograms, local pictograms are preferred over USP pictograms as they were kept simple, clear making it familiar and culturally acceptable as well as reflecting local traditions and habits resulting in easy understanding amongst the participants [19-22]. A study pointed out that patient have an important voice in the discussion by providing feedback enables in the modification and designing of the pictogram [13].

Lastly, in case of communication barrier, health care providers using challenging medical terminology, visual form of pictograms are well interpreted over verbal or text communication because displaying of information through visual images grabs the attention of the respondents making it understandable and facilitating long-term memory. It also helps to improve the credibility of the information provided. However, the best outcomes seen when pictograms were accompanied by verbal and text information to avoid misinterpretation $[\mathbf{1 1}, \mathbf{1 3}, \mathbf{1 5}]$. 


\section{CONCLUSION}

Pictograms can serves as a communication tool and have been receiving progressive attention in the recent years. The main intention of pictogram is to ease patient adherence and reduced potential risks or error associated with the used of medications. But in this review, literature studies showed that factors like age, cultural familiarity, education level and limited visual literacy may greatly cause a variation in their ability to convey correct meaning. Yet, prior counselling accompanied by recall test/postintervention can result in better understanding of the pictograms. Moreover, only 13 limited articles were selected to evaluate the potential understanding of the pictogram among the participants; so, to strengthen the outcome more studies should be implemented in this area by creating awareness by health care providers in order to provide a better and complete approach about pharmaceutical pictograms in the health care system.

\section{REFERENCES}

[1] Park J, Zuniga J. Effectiveness of using picture-based health education for people with low health literacy. Cogent Medicine 2016; 3: 1264679.

[2] Nichols-English G, Poirier S. Optimizing adherence to pharmaceutical care plans. J Am Pharm Assoc 2000; 40(4): 475-485.
[3] Mayeaux EJ, Murphy PW, Arnold C, Davis TC, Jackson RH, Sentell T. Improving patient education for patients with low literacy skills. Am Fam Physician 1996; 53(1): 205-211.

[4] Del RL, Villarreal G, Pouliot A. Pictograms: can they help patients recall medication safety instructions? Visible Language 2016; 50(1): 127151.

[5] Khatri S, Gehlaut R, Mishra N, Mittal P, Yadav S. Comparative analysis of awareness and understanding of pictograms in pharmacy and nonpharmacy students. Pharmacologyonline 2011; 3: 886-891.

[6] Hanson CE, Hartzema A. Evaluating pictograms as an aid for counselling elderly and low-literate patients. J Pharm Marketing and Management 1995; 9(3): 41-54.

[7] van Beusokom MM, Kerkhoven $\mathrm{AH}$, Bos MJW, Guchelaar HJ, van den Broek JM. The extent and effect of patient involvement in pictogram design for written drug information: A short systematic review. Drug Discov Today 2018; 23(6): 1312-1318.

[8] Dowse R, Ehlers MS. Pictograms for conveying medicine instructions: comprehension in various South African language groups. S Afr J Sci 2000; 100: 687-693. 
[9] Mishra N, Khatri S, Gehlaut R, Mittal P, Yadav S. Awareness and understanding of pharmaceutical pictogram in non-pharmacy students: A case study. Journal of Applied Pharmaceutical Science 2011; 1(10): 207-210.

[10] Banstola A. Awareness of pictogram among the undergraduate pharmacy students in a pharmacy college in Karnataka, India: A preliminary study. International Journal of Pharmacy and Therapeutics 2012; 3(3): 232-236.

[11] Joshi Y, Kothiyal P. A pilot study to evaluate pharmaceutical pictogram in a multispecialty hospital at Dehradun. Journal of Young Pharmacists 2011; 3: 163-166.

[12] Dowse R, Ehlers MS. Pictograms in Pharmacy. Int J Pharm Pract 1998; 6: 109-118.

[13] Merks P, Swieczkowski D, Balcerzak M, Drelich E, Bialoszewska K, Cwalina N, Zdanowski S, Krysinski J, Jaguszewski, Pouliot A, Villiancourt R. The evaluation of pharmaceutical pictograms among elderly patients in community pharmacy settings - A multicenter pilot study. Patient Prefer Adherence 2018; 12: 257-266.

[14]Khanji L, Xu S, Cavaco A. Assessing the understanding of pharmaceutical pictograms among cultural minorities: the example of Hindu individuals communicating European Portuguese. Pharmacy 2018; 6(1): 22.

[15] Mohamed LMA, Idris KAMA. Impact of newly designed, culturally sensitive pharmaceutical pictograms on medication information and use: Sudan study. World Journal of Pharmaceutical Research 2018; 7(8): 56-98.

[16]Zargarzadeh AH, Ahmadi S. Comprehensibility of selected United States Pharmacopeia pictograms by illiterate and literate Farsi speakers: The first experience in Iran - Part II. J Res Med Sci 2017; 22: 101.

[17]Barros IMC, Alcantara T, Mesquita AR, Bispo ML, Rocha CE, Moreira VP, Junior DPL. Understanding of pictograms from the United States Pharmacopeia Dispensing Information (USP-DI) among elderly Brazilians. Patient Prefer Adherence 2014; 8: 1493-1501.

[18] Sharif SI, Abdulla M, Yousif A, Mohamed D. Interpretation of pharmaceutical pictograms by pharmacy and non-pharmacy university students. Pharmacology and Pharmacy 2014; 5: 821-827.

[19]Knapp P, Raynor DK, Jebar AH, Price SJ. Interpretation of medication pictograms by adults in the UK. Ann Pharmacother 2005; 39: 1227-1233. 
[20] Dowse R, Ehlers M. Pictograms for conveying medicine instructions: comprehension in various South African language groups. South African Journal of Science 2004; 100(11): 687-693.

[21] Dowse R, Ehlers MS. The influence of education on the interpretation of pharmaceutical pictogram for communicating medicine instructions. International Journal of Pharmacy Practice 2003; 11: 11-18.

[22] Dowse R, Ehlers MS. The evaluation of pharmaceutical pictograms in a lowliterate South African population. Patient Education and Counseling 2001; 45(2): 87-99. 